\title{
The first report of chemical and biological study of essential oil from Begonia reniformis leaf (Begoniaceae)
}

\author{
Anne Gabrielle Marques da Silva ${ }^{1}$, Marcilio Wagner Fontes Silva ${ }^{1}$, Giselle Barbosa Bezerra ${ }^{1}$, Clécio Souza Ramos ${ }^{1+}$ (e) \\ ${ }^{1}$ Rural Federal University of Pernambuco, Department of Chemistry, Manoel de Medeiros St., Dois Irmãos, Recife 52171-030, Brazil
}

${ }^{+}$Corresponding author: Clécio Souza Ramos, phone: +55-81-3320-6379, e-mail address: clecio.ufrpe@gmail.com

\section{ARTICLE INFO}

Article history:

Received: September12, 2017

Accepted: November 27, 2017

Published: December 30, 2017
Keywords:

1. Begoniaceae

2. Begonia reniformis

3. antimicrobial

4. essential oil
ABSTRACT: Species of the genus Begonia are expensive ornamental plants. There have been few reports of chemical studies with the Begonia species. Here we report the first chemical and biological study of essential oil for a species of Begonia. The essential oil of the Begonia reniformis leaf obtained by hydrodistillation was analyzed via GC-MS and twenty-one compounds were identified. Sesquiterpenes silphiperfol-4,7(14)-diene and $\beta$-vetispirene were the major ones with a percentage of 15.7 and $21.0 \%$, respectively. The oil showed weak activity against bacteria Bacillus subtilis and Pseudomonas aeruginosa with minimum inhibitory concentrations of $625 \mu \mathrm{g} / \mathrm{mL}$ for each of the two bacteria.

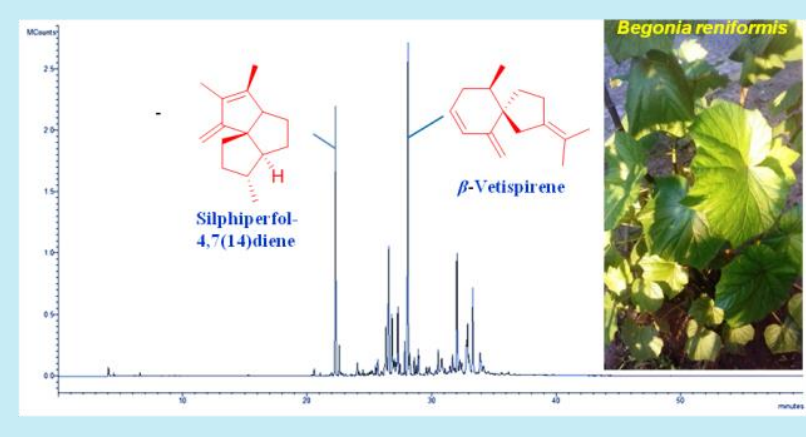

phytochemistry of leaf extracts of Begonia malabarica, the compounds friedelin, epi-friedelinol, $\beta$-sitosterol, luteolin, quercetin and $\beta$-sitosterol-3- $\beta$ - $D$ glucopyranoside were isolated ${ }^{7}$. From the Begonia picta species, the following flavonoids were isolated: vitexin, iso-vitexin, orientin, iso-orientin and 1,3dihydroxy-6,7-dimethoxyxanthone. The compounds orientin and iso-orientin were also identified, both of which showed potent antioxidant activity with $\mathrm{IC}_{50}$ values of 54.0 and $53.4 \mu \mathrm{mol} / \mathrm{L}$, respectively, when compared with a trolox positive control with an $\mathrm{IC}_{50}$ value of $96.1 \mu \mathrm{mol} / \mathrm{L}^{8}$. In other phytochemical studies, different classes of anthocyanins were isolated from the extracts of flowers of the Begonia sp species, while several steroids and flavonoids were isolated from $B$. evansiana and B. malaba-rica species ${ }^{7,9,10}$. Despite limited studies of the chemistry of the Begonia species, 
the few reports available point to flavonoids and steroids as chemotaxonomic metabolites for the genus.

In relation to studies on the chemistry of the essential oil obtained from the Begonia species, to our knowledge there are no reports, this work is the first to describe the chemical constituents of the essential oil for a Begonia species, the Begonia reniformis, a species that is part of the Brazilian flora. To date, we have found no chemical study previously reported for this plant.

\section{Experimental}

\subsection{Material botanic}

Begonia reniformis specimens were collected on the Campus of the Rural Federal University of Pernambuco, in the city of Recife, State of Pernambuco in the Northeastern of Brazil, in August 2016. The Instituto Agronômico de Pernambuco - IPA was asked to make the botanical identification and a voucher specimen was deposited at the Dárdano de Andrade Lima Herbarium of the IPA (90664).

\subsection{Obtaining of essential oils}

The essential oil was obtained from fresh leaf (250 g) via hydrodistillation using a Clevenger-type apparatus. The distillation was carried out for $3 \mathrm{~h}$. The oil obtained was treated with $\mathrm{Na}_{2} \mathrm{SO}_{4}$.

\subsection{Analysis of essential oil}

The essential oil was analyzed by GC-MS with a programmed temperature of $60-240^{\circ} \mathrm{C}$ at $3^{\circ} \mathrm{C}$ min rate in a Gas Chromatograph (Varian 431-GC) equipped with a fused-silica capillary column $(30 \mathrm{~m} \times 0.25 \mathrm{~mm}$ i.d. $\times 0.25 \mu \mathrm{m})$ coated with DB-5 and coupled to a Mass Spectrometer (Varian 220-MS). The detailed conditions of GC-MS analysis have been previously reported by our research group ${ }^{11,12}$. Identification of the chemical constituents was carried out using the Van den dool and $\mathrm{Kratz}^{13}$ equation and comparing with published mass spectra ${ }^{14}$.

\subsection{In vitro assay for antimicrobial activity}

The antimicrobial potential of essential oil obtained of $B$. reniformis leaves was evaluated against the bacteria Staphylococcus aureus (ATCC 6538), Bacillus subtilis (ATCC 6633), Escherichia coli (UFPEDA 224) and Pseudomonas aeruginosa (ATCC 416) as well as against the fungi Candida albicans (ATCC 1007) and Candida utilis (ATCC 1009). The microorganisms were maintained in nutrient agar (NA), stored at $4{ }^{\circ} \mathrm{C}$. The antimicrobial activity evaluation was performed by determination of the values of minimum inhibitory concentrations (MIC) as previously reported ${ }^{11,12}$. The antimicrobials Metronidazol and Fluconazol were used as the positive control.

\section{Results and discussion}

Essential oil $(78 \mathrm{mg}$ ) from a mass of the fresh leaves of $B$. reniformis $(250 \mathrm{~g})$ was obtained with a yield of $0.03 \%$. The chemical profile of essential oil of B. reniformis leaves obtained by GC-MS showed two major peaks at 22.2 and 28.1 minutes with relative concentrations of 15.7 and $21.0 \%$, respectively (Figure 1). Major peaks at 22.2 and 28.1 minutes were identified as sesquiterpenes silphiperfol-4,7(14)-diene and $\beta$-vetispirene, respectively. A total of 21 compounds were identified representing $84.8 \%$ of the analyzed oil (Table 1), such as (-)-cis-cadine-1(6),4diene $(7.1 \%)$, ishwarane $(3.9 \%)$, Guaiol $(8.0 \%)$, cismuurola-3,5-diene (3.5\%), trans-muurola-3,5-diene (3.7\%), dauca-5,8-diene (4.3\%) and $\beta$-atlantol (2.9\%). To our knowledge there has been no report of chemical and biological studies of the essential oils of species from Begoniaceae family that has included the genera Begonia and Hillebrandia. The major compound of essential oil from $B$. reniformis leaves, sesquiterpene $\beta$ vetispirene, has been previously reported in the essential oils from Vetiveria zizanioides (Poaceae) roots $^{15}$, and its occurrence in other plant species is rare. The second major oil compound has been reported in about fifteen plant species, such as Remirea maritima (Cyperaceae), Piper amalago (Piperaceae), Artemisia vulgaris (Asteraceae), Clinopodium vulgare (Labiatae) and Lomatium rigidum (Apiaceae) ${ }^{16-20}$. 


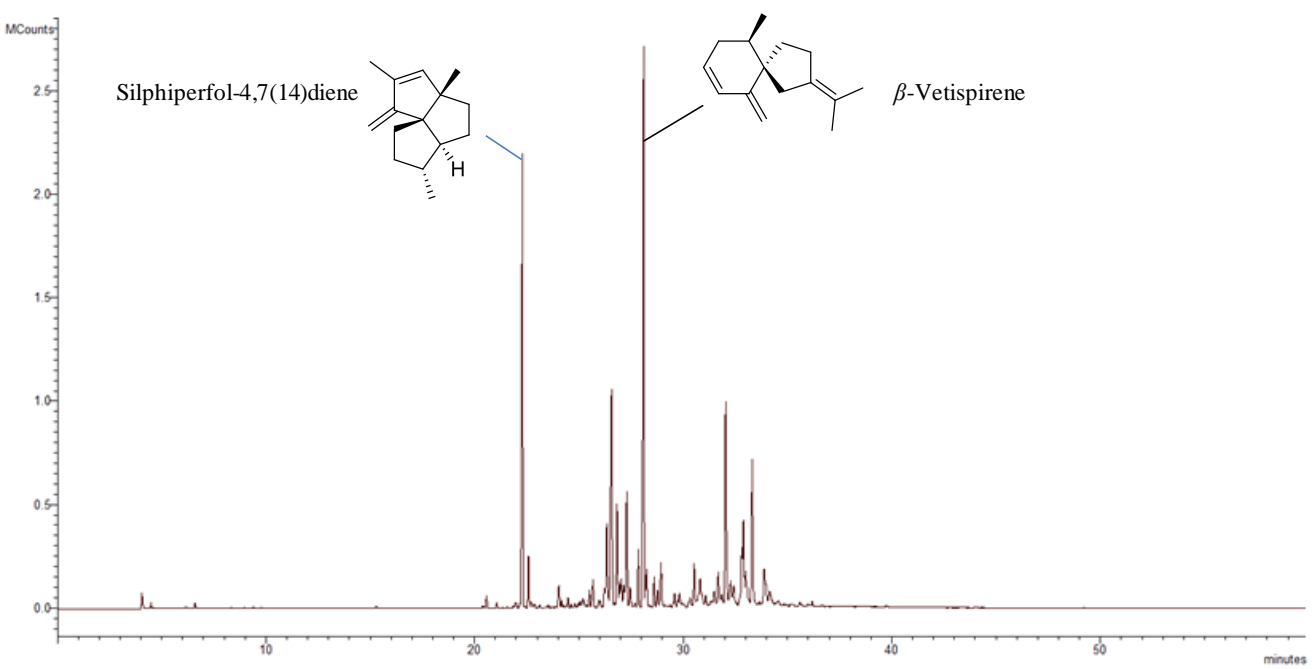

Figure 1. Chromatogram of essential oil of the B. reniformis leaf obtained via GC-MS.

Table 1.Chemical constituents identified in the essential oil of the B. reniformis leaf.

\begin{tabular}{|c|c|c|c|}
\hline Compounds $^{\text {a }}$ & $\mathrm{AI}^{\mathrm{b}}$ & $\mathrm{AI}^{\mathrm{c}}$ & Relative amount (\%) \\
\hline 1. Silphiperfol-4,7(14)-diene & 1356 & 1358 & 15.7 \\
\hline 2. Cyclosativene & 1363 & 1369 & 1.5 \\
\hline 3. Isobazzanene & 1432 & 1436 & 1.0 \\
\hline 4. cis-Muurola-3,5-diene & 1448 & 1448 & 3.5 \\
\hline 5. trans-Muurola-3,5-diene & 1454 & 1451 & 3.7 \\
\hline 6. (-)-cis-Cadina-1(6),4-diene & 1455 & 1461 & 7.1 \\
\hline 7. Ishwarane & 1460 & 1465 & 3.9 \\
\hline 8. cis-Muurola-4(14),5-dieno & 1465 & 1465 & 1.0 \\
\hline 9. Dauca-5,8-diene & 1471 & 1471 & 4.3 \\
\hline 10. trans-Cadina-1(6),4-diene & 1474 & 1475 & 2.0 \\
\hline 11. $\beta$-Vetispirene & 1490 & 1493 & 21.0 \\
\hline 12. trans-Muurola-4(14),5-diene & 1493 & 1493 & 1.2 \\
\hline 13. Epizonarene & 1502 & 1501 & 1.0 \\
\hline 14. Vanillin acetate & 1518 & 1524 & 1.8 \\
\hline 15. Raspberry ketone & 1549 & 1545 & 1.3 \\
\hline 16. $\beta$-Copaen-4- $\alpha$-ol & 1586 & 1590 & 1.1 \\
\hline 17. Carotol & 1593 & 1594 & 1.2 \\
\hline 18. Guaiol & 1587 & 1600 & 8.0 \\
\hline 19. $\beta$-Atlantol & 1608 & 1608 & 2.9 \\
\hline 20. 1,10-di-epi-Cubenol & 1611 & 1618 & 1.0 \\
\hline 21. cis-Cadin-4-en-7-ol & 1634 & 1635 & 0.6 \\
\hline Unidentified terpenes ${ }^{\mathrm{d}}$ & & & 10.5 \\
\hline Unidentified fatty acids ${ }^{\mathrm{e}}$ & & & 1.1 \\
\hline Unknown compounds & & & 3.6 \\
\hline
\end{tabular}

Total of compounds identified: $84.8 \%$

${ }^{a}$ Compounds are listed in ascending order of their retention times. AI: Arithmetic index. ${ }^{b}$ Arithmetic index as determined on non-polar DB-5 column. ${ }^{\mathrm{c}}$ Arithmetic index of the literature. ${ }^{\mathrm{d}, \mathrm{e}}$ Determined by the fragmentation pattern of their respective mass spectra. 
The essential oil of B. reniformis leaf was evaluated against six microorganisms including fungi, grampositive bacteria and gram-negative bacteria to determine the MIC values by the agar dilution method. The samples of natural source as extract and essential oil that show MIC values lower than $100 \mu \mathrm{g} / \mathrm{mL}$ are characterized as strong antimicrobial agent. The samples with MIC values ranging from 100-500, 5001000 and over $1000 \mu \mathrm{g} / \mathrm{mL}$ are considered to be moderately weak, or non-active, respectively, against fungi and bacteria according to criteria in the literature $^{21}$. The results in Table 2 show that the oil was biologically active against gram-positive bacteria $B$. subtilis and gram-negative bacteria $P$. aeruginosa with MIC of $625 \mu \mathrm{g} / \mathrm{mL}$ for each of the two bacteria, this is considered to be weak activity.

Table 2. Values of the MIC obtained for essential oil from the B. reniformis leaf towards bacteria and fungi

\begin{tabular}{|c|c|}
\hline \multicolumn{2}{|c|}{ Bacteria } \\
\hline \multicolumn{2}{|c|}{ Gram-positive bacteria } \\
\hline Staphylococcus aureus & $>2500 \mu \mathrm{g} / \mathrm{mL}$ \\
\hline Bacillus subtilis & $625 \mu \mathrm{g} / \mathrm{mL}$ \\
\hline \multicolumn{2}{|c|}{ Gram-negative bacteria } \\
\hline Escherichia coli & $>2500 \mu \mathrm{g} / \mathrm{mL}$ \\
\hline Pseudomonas aeruginosa & $625 \mu \mathrm{g} / \mathrm{mL}$ \\
\hline \multicolumn{2}{|c|}{ Fungi } \\
\hline Candida albicans & $>2500 \mu \mathrm{g} / \mathrm{mL}$ \\
\hline Candida utilis & $>2500 \mu \mathrm{g} / \mathrm{mL}$ \\
\hline
\end{tabular}

\section{Conclusions}

The first study on the chemical composition of the essential oil for a species of the Begoniaceae family showed sesquiterpenes as the major constituents in the $B$. reniformis leaf. The sesquiterpenes silphiperfol4,7(14)-diene and $\beta$-vetispirene were the majority and these are rare in the essential oil of plant. The essential oil showed weak antimicrobial activity against the bacteria $B$. subtilis and $P$. aeruginosa.

\section{Acknowledgments}

The authors are indebted to the Centro de Apoio a Pesquisa (CENAPESQ), UFRPE, for the laboratory facilities. AGMS thanks CAPES for providing a scholarship.

\section{References}

[1] Forrest, L. L., Hughes, M., Hollingsworth, P. M.,A Phylogeny of Begonia Using Nuclear Ribosomal Sequence Data and Morphological Characters, Syst, $\begin{array}{lrr}\text { Botany } & 3(2005) & 671-682 . \\ \text { https://doi.org/10.1600/0363644054782297 } & \end{array}$

[2] Christenhusz, M. J. M., Byng, J. W., The number of known plants species in the world and its annual increase, Phytotaxa 261(2016) 201-217. https://doi.org/10.11646/phytotaxa.261.3.1

[3] Clement, W. L., Tebbitt, M. C., Forrest, L. L., Blair, J. E., Brouillet, L., Eriksson, T., Swensen, S. M., Phylogenetic position and biogeography of Hillebrandia sandwicensis (Begoniaceae): a rare Hawaiian relict, Am. J. Bot. 9(2004) 905-917. https://doi.org/10.3732/ajb.91.6.905

[4] Chan, Y. M., Twyford, A. D., Tnah, L. H., Lee, C. T., Characterisation of EST-SSR markers for Begonia maxwelliana (Begoniaceae) and cross-amplification in 23 species from 7 Asian sections, Sci. Hortic. 190(2015)70-74.

https://doi.org/10.1016/j.scienta.2015.04.012

[5] Kollmann, L. J. C., Flora das cangas da Serra dos Carajás, Pará, Brasil: Begoniaceae, Rodriguésia 67 (2016) 1247-1252. https://doi.org/10.1590/21757860201667522

[6] Kollmann, L. J. C., Peixoto, A. L., Notas sobre a distribuição e registro de ampliação de áreas de 
ocorrência de quatro espécies de Begonia da floresta atlântica brasileira, Rodriguésia 65 (2014)193-200. https://doi.org/10.1590/S2175-78602014000100013

[7] Ramesh, N., Viswanathan, M. B., Saraswathy, A., Balakrishna, K., Brindha, P., LakshmanaperumalSamy, P., Phytochemical and antimicrobial studies of Begonia malabarica, J. Ethnopharmacol. 79(2002) 129-132. https://doi.org/10.1016/S03788741(01)00352-X

[8] Joshi, K. R., Devkota, H. P., Nakamura, T., Watanabe, T., Yahara,S.,Chemical Constituents and their PPH Radical Scavenging Activity of Nepa-lese Crude Drug Begonia picta, Rec. Nat. Prod. 9(2015) 446-450.

http://www.acgpubs.org/RNP/2015/Volume9/Issue \%2 01/56-RNP-1407-160.pdf

[9] Nadine, C., Maurice, J., Acylated anthocyanins from flowers of Begonia, Phytochemistry 40(1995) 275-277.

9422(95)00073-G

[10] Zhangand, J., Chen,Y., Studies on the chemical constituents of Begonia evansiana Andr, China J. Chinese Mat.Med. 22(1997) 295-296. http://en.cnki.com.cn/Article_en/CJFDTOTALZGZY705.017.htm

[11] Silva, A. S., Silva, J. M., Almeida, A. V., Ramos, C. S., Herbivory Causes Chemical and Biological Changes on Essential Oil from Piper marginatum Leaves, The Nat. Prod. J. 6(2016) 313-317. https://doi.org/10.2174/2210315506666160916152524

[12] Rocha, D. S., Silva, J. M., Navarro, D. M. A. F., Camara, C. A. G., Lira C. S. d Ramos, C. S., Potential Antimicrobial and Chemical Composition of Essential Oils from Piper caldense Tissues, J. Mex. Chem. Soc. 60(2016) $148-151$. http://www.redalyc.org/articulo.oa?id=47548008007

[13] Kovats, E. S., Gas chromatographic characterization of organic substances in the retention index system, Adv. Chromatogr. 16(1965) 229-247. http://garfield.library.upenn.edu/classics1988/A1988 M801800001.pdf

[14] Adams, R. P., Identification of Essential Oil Components by Gas Chromatography/Mass Spectrometry, Allured Publ. Corp., Carol Stream, 2007, 4th edn.

[15] Champagnat, P., Figueredo, G., Chalchat, J. C., A study on the composition of commercial Vetiveria zizanioides oils from different geographical origins, J. Essent. Oil Res. 18(2006) 416-422. https://doi.org/10.1080/10412905.2006.9699129
[16] Beauchamp, P. S., Descalzo, J. T., Dev, B. C., Dev, V., Nguyen, C. V., Midland, S. L., Sims, J. J., Tham,F. S., California lomatiums, part IV: composition of the essential oils of Lomatium rigidum (M. E. Jones) jepson. Structures of two new funebrene epimers and a tridecatriene, J. Essent. Oil Res.16 (2004)571-578.

https://doi.org/10.1080/10412905.2004.9698801

[17] Mota, J. S., Daiane, S. S., Boone, C. V., Cardoso, C. A. L., Caramao,E. B., Identification of the Volatile Compounds of Leaf, Flower, Root and Stem Oils of Piper amalago (Piperaceae), J. Essent. Oil Bear. Pl.16(2013)11-1.

https://doi.org/10.1080/0972060X.2013.794021

[18] Sujatha, G., Zdravkovic-Korac, S., Calic, D., Flamini, G.,Ranjitha-Kumari,B. D., High-efficiency Agrobacterium rhizogenes-mediated genetic transformation in Artemisia vulgaris: Hairy root production and essential oil analysis, Ind. Crops. Prod. 44(2013) 643-652. https://doi.org/10.1016/j.indcrop.2012.09.007

[19] Rabelo, A, S., Serafini, M. R., Rabelo, T. K., Garcez Gloria de Melo, M., Silva Prado, D. da, Pens Gelain, D., Fonseca Moreira, J. C., Santos Bezerra, M. dos, Brasil da Silva, T., Vilaça Costa, E., Lima Nogeuira, P. C. de, Souza Moraes, V. R., Nascimento Prata, A. P. do, Quintanas Jr., L. J., Souza Araújo, A. A., Chemical composition, antinociceptive, antiinflammatory and redox properties in vitro of the essential oil from Remirea maritime, Aubl. (Cyperaceae), BMC Bioinformatics15(2014) 1-514. https://doi.org/10.1186/1472-6882-14-514

[20] Iran, M-S.K., Saeedi, M., Akbarzadeh, M. The essential oil composition of Clinopodium vulgare L from Iran, J. Essent, Oil Res.21(2009) 31-32. https://doi.org/10.1080/10412905.2009.9700100

[21] Holetz, F. B., Pessini, G. L., Sanches, N. R., Garcia Cortez, D. A., Nakamura, C. V., Dias Filho, B. P., Screening of some plants used in the Brazilian folk medicine for the treatment of infectious diseases, Mem. Inst. Oswaldo Cruz 97(2002)1027-1031. https://doi.org/10.1590/S0074-02762002000700017 